\title{
A VERDADE QUE ESTÁ NO ERRO \\ A IMPORTÂNCIA DO ESTATUTO DA CIDADE PARA A (RE)VALORIZAÇÃO DO ESPAÇO
}

Sérgio Martins

Professor do Programa de Pós-graduação em Geografia da Universidade Federal de Minas Gerais sergiomartins@ufmg.br

Gláucia Carvalho Gomes Professora do Instituto de Geografia da Universidade Federal de Uberlândia glau@ufu.br

\section{Resumo}

Os autores examinam o chamado Estatuto da Cidade destacando sua importância como quadro institucional para os capitais que atuam na urbanização definida enquanto espacialidade aprestável para a valorização, na medida em que fortalece as estratégias implicadas na capitalização das rendas fundiárias.

Palavras-chave: Urbanização; (re)valorização do espaço; verdade-poder.

\section{Abstract}

The authors examine the so called Statute of the City emphasizing its importance as institutional framework for the capitals that act in urbanization, defined as space prepared for valuation, to the point that it strengthens the strategies implicated in the capitalization of land property revenues.

Key-words: urbanization; (re)valuation of space; truthpower; city.

\section{$0 \bigcirc 0$}

Um tal movimento, operado sob o abrigo do Estado, será reencontrado várias vezes: a esquerda fornece a ideologia e as idéias que a direita recupera (facilmente). [...] Ela deixa a esquerda se aventurar no árduo terreno das inovações, das reformas, das modernizações que não atingem nem o modo de produção, nem o Estado. (LEFEBVRE, 1976).

Ainda hoje a investigação da verdade possui o charme de contrastar fortemente com o erro, agora cinzento e tedioso; mas esse charme está se perdendo. Sem dúvida ainda vivemos a juventude da ciência, e costumamos ir atrás da verdade como de uma bela jovem; e quando ela tiver se tornado uma velha carrancuda?

(NIETZSCHE, 2007).

Não foram poucos os estudiosos da questão urbana que saudaram a regulação dos artigos 182 e 183 da Constituição de 1988 pela lei 10.257, promulgada em 2001 (e intitulada Estatuto da Cidade) ${ }^{1}$, como uma conquista dos chamados movimentos sociais urbanos. Entre os geógrafos, uma intelectual organicamente ligada a tais movimentos assim se exprimiu: "Trata-se de uma lei construída com participação ativa dos movimentos da sociedade civil que lutam pela reforma urbana. Em 1988 apresentaram ao Congresso Constituinte a Emenda Popular pela Reforma Urbana que já continha os germes dos Instrumentos do Estatuto" (RODRIGUES, 2004, p.90).

$\mathrm{Na}$ medida em que o curso da modernização das metrópoles brasileiras prossegue triunfalmente, é possível tomar distância em relação ao que foi dito para compreender melhor o sentido geral do que foi

Revista da ANPEGE. v. 5, 2009 
(e prossegue sendo) feito sob o abrigo de tal quadro institucional. Tratamos, aqui, de destacar a reafirmação e ampliação, contemplados no Estatuto da Cidade, dos fundamentos da mobilização da propriedade territorial no âmbito da valorização do espaço. O desafio teórico consiste, portanto, em demonstrar que as determinações concretas da urbanização capitalista não apenas permanecem intocadas pelo aprisionamento da política nas formas do Estado, como são reiteradas e desenvolvidas as intrincadas contradições que envolvem a reprodução social das metrópoles, e nelas se sintetizam, especialmente se considerarmos a decisiva importância que a capitalização da renda da terra desempenha em tal processo.

Sabemos, desde Marx, que a propriedade privada de terras, que precede historicamente o modo de produção capitalista, foi mantida e incorporada às suas tramas reprodutivas não apenas porque foi (e prossegue sendo) condição necessária para a formação de capitais e para a proletarização ${ }^{2}$. Ao se referir à renda da terra como forma historicamente específica que a propriedade fundiária adquire na sociedade capitalista, Marx ([1894] 1991, p.709) advertiu que a dissociação da propriedade fundiária das antigas relações de sujeição permitiu a apropriação da renda desvinculada do uso efetivo das terras por seus proprietários, a tal ponto que "os donos de terras na Escócia podem passar toda a vida em Constantinopla". Sob tal forma, a valorização econômica da propriedade fundiária deixa de pressupor a intervenção dos seus beneficiários, uma vez que o monopólio sobre um pedaço do globo terrestre capacita uma classe social específica, a dos proprietários fundiários, que não são proprietários de capitais, a cobrar um tributo, a renda fundiária absoluta, uma parcela da riqueza social para cuja produção em nada participa ou arrisca. Em torno do fato histórico de que proprietários de terras absenteístas possam captar uma fração da riqueza socialmente produzida sem que precisem sequer tocar a terra com seus dedos, desdobrou-se o debate teórico e político, advindo da economia política e retomado criticamente por Marx, acerca do chamado caráter parasitário (e portanto supérfluo) dos proprietários de terras.

Constituindo-se inicialmente como uma barreira aos investimentos de capitais nas atividades nas quais a terra é meio de produção fundamental, a renda fundiária absoluta não apenas solapa a capacidade individual de produção dos capitais nessas esferas ${ }^{3}$, como se liga à manutenção da composição orgânica de tais capitais abaixo da média social, interferindo, assim, no estabelecimento dos preços de mercado acima dos preços de produção, na medida em que a definição daqueles envolve a remuneração da propriedade fundiária. Assim, o desenvolvimento das forças produtivas sob esta forma social historicamente específica se defrontaria não apenas com um entrave, mas com uma irracionalidade historicamente herdada. Porém, apesar dos radicalismos burgueses - como a estatização das terras e a reforma agrária, que busca(ra) $\mathrm{m}$ romper os entraves pré-capitalistas ao crescimento econômico suprimindo a propriedade privada das terras e, assim, aniquilar a classe dos proprietários fundiários -, a importância da renda fundiária não apenas se manteve, como recrudesceu e se complexificou. E isso não apenas porque os proprietários de terras sobreviveram e se reergueram mesmo onde seu monopólio foi combatido, ou mantiveram, senão ampliaram, considerável peso (político e econômico), como é o caso da sociedade brasileira ${ }^{4}$.

Marx sempre destacou que toda renda fundiária é produto de mais-valia, de trabalho excedente. Não se trata, portanto, de um poder independente, como se a renda fundiária tivesse sua origem numa espécie de base natural da propriedade territorial para gerá-la. Trata-se de uma criação histórica específica que pressupõe determinadas relações sociais. Assim como o capital não se valoriza sozinho, como se tivesse o diabo no corpo, a propriedade territorial não cria a renda como num passe de mágica. Daí o equívoco de se representar as formas e as fontes da riqueza socialmente produzida de uma perspectiva estritamente fenomênica, considerando os elementos da produção separados entre si e negligenciar que estão entrelaçados organicamente numa totalidade ${ }^{5}$. Preservado no quadro geral da propriedade privada, 
o monopólio da propriedade de terras tem, portanto, implicações consideráveis para a acumulação capitalista, para além das condições constituídas pela renda absoluta. Sem esquecer que os detentores do monopólio da exploração confrontam-se com os proprietários fundiários não apenas por estes exigirem a renda absoluta, como também por reterem, mesmo em sua passividade, partes da renda diferencial ${ }^{6}$, é preciso lembrar que os capitais, movimentando-se no quadro do monopólio das terras, portanto num quadro que dificulta o livre fluxo dos capitais de uma esfera à outra, alcançam lucros extraordinários sob a forma de rendas capitalizadas. Não são, portanto, apenas as taxas médias de lucro que orientam os investimentos nessas esferas, mas também as possibilidades de obtenção de lucros máximos, sob a forma de rendas diferenciais, que exercem tal caráter reitor.

Retomando e desenvolvendo de modo acurado a elaboração teórica marxiana, David Harvey destacou a imensa controvérsia e confusão nos estudos esteados na teoria do valor ao se depararem com a renda fundiária. Nesse campo minado, como dizia o geógrafo inglês, poucas almas valorosas conseguiram encontrar caminho. Harvey, que seguramente é uma dessas almas, chamou a atenção para a permanência da insuficiente concepção limitada à renda absoluta como base para compreender e explicar a economia política do espaço no capitalismo contemporâneo.

La propiedad territorial y la apropiación de la renta modifican considerablemente a la corriente de capital hacia la tierra y a través de ella como una condición y un medio de producción. Aunque se ha dicho mucho sobre la 'barrera' que el capital terrateniente opone a la corriente de capital, y de los efectos negativos de las apropiaciones de la renta sobre la acumulación, resulta ser que la propiedad territorial también desempeña un papel para obligar a colocar correctamente el capital en la tierra. La dificultad está en asegurar el incremento de este papel positivo y en restringir al mismo tiempo el negativo.

En el caso del monopolio y de la renta absoluta, la propiedad territorial pone barreras que son difíciles de justificar en relación con los requerimientos básicos del capitalismo. Por tanto, la apropiación de estas formas de renta se debe considerar como una influencia totalmente negativa sobre la colocación correcta de capital a la tierra, y en consecuencia, a la formación de precios de mercado válidos y al sostenimiento de la acumulación. Por esta razón, es evidente que al capital en general le interesa mantener las rentas absolutas y de monopolio dentro de límites estrictos, para asegurar que sigan siendo pequeñas (como Marx insistió que debían ser) y que ocurran esporádicamente.

El problema más interesante surge en el caso de la compleja interacción entre las dos formas de renta diferencial que [...] puede tener efectos positivos, negativos o neutrales sobre la formación de los precios del mercado, la concentración y dispersión del capital, y la acumulación. Desgraciadamente, gran parte de la polémica dirigida contra la renta de monopolio y la renta absoluta y contra el papel parasitario y superfluo del terrateniente en esas situaciones, se ha trasladado al análisis de la renta diferencial. Por tanto, se han subrayado los aspectos negativos de las intervenciones de la propiedad territorial, y se ha prestado poca atención al papel positivo de coordinar la corriente de capital a la tierra y a través de ella en formas que apoyan ampliamente la acumulación ulterior. (HARVEY, [1982] 1990, p.362-364, grifos do autor).

Ora, o que se compra e vende, como sublinhou Marx, não é a terra propriamente dita, mas o direito à renda que se pode obter, o direito a rendas futuras, que residem, evidentemente no trabalho social a ser desenvolvido.

Los dueños de tierras que las tratan como un bien financero puro realizan exactamente una tarea de este tipo. Coaccionan al capital (elevando las rentas, por ejemplo) o cooperan con él para asegurar la creación de rentas más altas de la tierra. [...] El significado de estos poderes de coordinación, junto con sus consecuencias negativas, son particularmente evidentes cuando se llega al problema de la organización espacial [...]. El

Revista da ANPEGE. v. 5, 2009 
mercado de tierras da forma a la asignación de capital a la tierra y así da forma a la estructura geográfica de la producción, intercambio y consumo, la división técnica del trabajo en el espacio, los espacios socioeconómicos de reproducción, etc. Los precios de la tierra forman señales a las cuales pueden responder que sirve para racionalizar las estructuras geográficas en relación con la competencia. [...] El problema con esta solución es que, aunque los mercados de tierras pueden estar mejor coordinados, pueden quedar expuestos más directamente a todos los problemas inherentes del proprio sistema de credito. (HARVEY, [1982] 1990, p.371-373)

Apesar das questões implicadas pela renda fundiária terem sido negligenciadas, ou mesmo esconjuradas de muitas elaborações teóricas acerca da reprodução social capitalista, as contradições concretas se multiplicam e se desenvolvem praticamente, reproduzindo-se ampliadamente na e pela urbanização. Porém, apesar de distintos historicamente e distinguíveis teoricamente, ambos os monopólios, o dos proprietários de terras e o dos proprietários de capitais, se entrelaçaram em torno das diferentes formas de renda fundiária, fusionando seus interesses imediatos a ponto de dificultar a determinação dos antagonismos, conflitos, articulações e solidariedades existentes entre eles ${ }^{7}$.

Empero, si ahondamos dentro de esta diversidad podemos comenzar a detectar una característica central de guia en la conducta de todos los agentes económicos, independientemente de quiénes son y de qué les dictan sus intereses immediatos: es la creciente tendencia a tratar a la tierra como un puro bien financiero. Aquí está la clave de la forma y de los mecanismos de la transición a la forma puramente capitalista de propiedad privada de la tierra. (HARVEY, [1982] 1990, p.349-350).

A crescente capitalização das rendas fundiárias nos circuitos dos mercados financeiros, com a circulação de títulos que dão direito aos seus detentores de se apropriarem de rendas futuras, complexificou de tal modo o mercado imobiliário que não se pode compreendê-lo considerando apenas a racionalidade que orienta os proprietários fundiários. Foi o que demonstrou Adriano Botelho (2007), em alentada pesquisa:

Em 1997, foi promulgada a lei 9.514, que estabeleceu o Sistema Financeiro Imobiliário (SFI) [...]. Trata-se de um sistema de financiamento complementar ao SFH (que não deixou de existir com a criação do SFI). Foram então realizadas inovações no financiamento imobiliário nacional, com a criação de instrumentos de securitização imobiliária, ou seja, que possibilitavam a transformação de bens imóveis em títulos mobiliários, como os Fundos de Investimento Imobiliário (FIIs) e os Certificados de Recebíveis Imobiliários (CRIs). A lei que criou o SFI introduziu também um novo veículo legal denominado Companhia Securitizadora de Créditos Imobiliários, sociedades com propósitos de fazer a securitização dos recebíveis imobiliários através da emissão dos CRIs, títulos imobiliários equivalentes a debêntures.

São inovações que buscam articular o setor imobiliário com o mercado financeiro, estabelecendo um processo de desintermediação bancária para o financiamento da produção, ao mesmo tempo em que oferecem possibilidades de ganhos financeiros aos investidores. [...]

Ambos são formas de securitização de ativos imobiliários, cujo sentido é a conversão de ativos de pouca liquidez em títulos mobiliários de grande liquidez, passíveis de serem absorvidos pelo mercado financeiro. Esses ativos possuem como lastro os imóveis que foram securitizados [...]

O mecanismo da securitização amplia as possibilidades de captação de recursos e acesso a financiamento aos 'originadores' desses créditos (as empresas que produzem os ativos a serem securitizados, como as incorporadoras, construtoras, etc.), dando acesso direto ao mercado de capitais, reduzindo, teoricamente, os custos e riscos da captação de recursos financeiros. A securitização também possibilitaria um giro maior do capital das empresas, que receberiam dos investidores os recursos e repassariam para estes seus créditos representados pelos ativos. Por exemplo, uma incorporadora, após vender as unidades de um edifício por ela 
construído, pode securitizar as dívidas dos adquirentes e vendê-las no mercado. Receberia, assim, de volta, o capital utilizado para financiar os compradores, e poderia reinvestir esse capital em outra atividade ou outro empreendimento. Os investidores que compraram os títulos, por sua vez, passariam a receber os juros e a amortização das dívidas diretamente dos adquirentes. Dessa forma, a incorporadora não necessitaria esperar pelo vencimento da dívida dos mutuários para recuperar o capital investido, podendo, assim, acelerar o tempo de rotação do capital imobilizado no empreendimento. [...]

Com a securitização, a questão da extração da renda fundiária é de certa forma absorvida e mascarada no processo de valorização imobiliário-financeira dos ativos, transformando-se em direitos de receber uma renda, obscurecida sob a forma de juros provenientes de um ativo imobiliário fragmentado em títulos (desabsolutização da propriedade imobiliária), com a mediação do capital financeiro. Não é mais a propriedade de um bem imóvel que garante a renda, mas sim a propriedade do direito de extrair, a partir de um empréstimo, além da renda presente no imóvel, os juros do capital adiantado. Juros e renda aparentemente se confundem. Dessa forma, saber a localização no espaço urbano dos imóveis securitizados pode indicar o papel da renda fundiária, pois estes imóveis devem se localizar nas áreas mais valorizadas das cidades para render o máximo possível.

Tanto os FIIs como os CRIs, embora representem uma etapa superior de financeirização da propriedade imobiliária, contribuindo para a sua desabsolutização, têm, como lastro, uma propriedade de um bem real, e seus rendimentos dependem da valorização desse bem. [...]

Dessa forma, como empreendimentos de mercado voltados para as camadas de rendimentos mais altos da população, acentuam o caráter de fragmentação e hierarquização do espaço urbano, ao concentrarem seus investimentos em áreas já valorizadas, aumentando a distância socioeconômica que separa essas áreas do restante da cidade. E o poder de intervenção no espaço urbano das empresas do setor imobiliário se amplia com a aliança com o setor financeiro, garantindo recursos necessários tanto para a superação da barreira colocada pelos altos preços da terra urbana quanto para a aceleração do tempo de rotação do capital no setor da construção. (p.166-192).

A conversão da renda da terra numa forma de capital fictício, com os títulos de propriedade trocandose como um bem financeiro puro, não significa que a renda fundiária tenha perdido sua importância nos investimentos dos capitais que atuam no âmbito do chamado setor imobiliário ${ }^{8}$. Pelo contrário, fortaleceu o caráter rentista dos mesmos ${ }^{9}$, bem como sua importância no conjunto da reprodução espacial da urbanização. Na tríade terra-capital-trabalho - a santíssima trindade da economia política, como alcunhara Marx - cada um desses elementos parece dotado de vida própria, seguindo modos de existência na aparência independentes uns dos outros. Ou, nas palavras do próprio Marx (1985), “os agentes da produção capitalista vivem num mundo enfeitiçado, e suas próprias relações afiguram-se-lhes atributos das coisas, dos elementos materiais da produção.” (p.1550). Talvez devêssemos atualizar essa assertiva. Novamente com a ajuda do próprio Marx (1989), basta considerar que apesar de nos encontrarmos num terreno (para usar uma metáfora apropriada) de tamanhas evidências empíricas de que "lo concreto es concreto porque es la síntesis de múltiples determinaciones, por lo tanto, unidad de lo diverso", e "las abstracciones más generales surgen únicamente allí donde existe el desarrollo concreto más rico, donde un elemento aparece como lo común a muchos, como común a todos los elementos. Entonces, deja de poder ser pensado solamente bajo una forma particular" (p.21-25), a noção de especulação imobiliária, per se, filha da economia vulgar, toscamente próxima da elaboração atolada teoricamente na consideração da propriedade da terra pela perspectiva da renda absoluta, há muito e ainda hoje é utilizada amplamente, inclusive em textos que se pretendem acadêmicos, como referência "conceitual" para explicar a economia política do espaço.

Revista da ANPEGE. v. 5, 2009 
Embora pouco ou nada ajude a compreender do que se trata, a importância dessa noção reside menos em sua capacidade teórica (de resto, nula) que em seu caráter mistificador. Afinal, é próprio da má-consciência prosseguir confiante, esconjurando tudo o que possa ser inextricável ou inquietante. A má-consciência quanto à natureza supostamente não-problemática da acumulação capitalista é mesmo necessária para que se possa levar adiante a empreitada mistificadora de sua reprodução. Nos dias que seguem, por exemplo, a mídia prossegue repleta de notícias quanto aos vultosos recursos destinados pelos diversos Estados para tentar amainar as conseqüências da "febre" especulativa atual, buscando localizar suas causas num nicho, num setor específico, quando, na verdade, estamos diante de evidências muito poderosas da reprodução social levada a cabo por um corpo social "enfermo", atrelando decisivamente a produção e reprodução espacial à órbita do capital financeiro. Quanto mais as determinações fundamentais da reprodução abstrata da riqueza sob a forma valor, com as contradições que lhe são próprias, ganham a luz do dia e se enraízam no corpo social, chegando inequivocamente a transformar o espaço literalmente num campo para a valorização, ampliando as contradições nas quais se movimenta a acumulação capitalista, mais as tentativas da cura pelo veneno sancionam as alienações, enfraquecendo ou mesmo interditando a crítica, esterilizando não apenas o pensamento teórico, como a ação politicamente transformadora dos fundamentos reais da sociedade.

A análise crítica, porém, não se resolve esconjurando as mistificações. Que os "sábios" da urbanização ainda se valham de noções teoricamente confusas e equivocadas, que povoem tranquilamente o mundo enfeitiçado dos agentes da produção, não causa surpresas. O saber, demonstrara finamente Michel Foucault, não se opõe ao poder, ou não nasce ali onde o poder está ausente, fora dele, ao largo e quiçá contra ele. Nas sociedades disciplinares, o saber, com seus instrumentos e suas técnicas, com a definição de seus métodos e do domínio de seus objetos, a formação de seus enunciados, a constituição de suas práticas discursivas... só existe porque é investido de prerrogativas para o exercício de um poder que desdobra seus efeitos na vida social a um nível molecular que insidiosamente o naturaliza, invisibilizando-o nas e pelas práticas que se tornam cotidianas, menos por conta de suas astúcias e habilidades para ser dificilmente localizável e discernível, mas porque o saber assegura a existência e a atuação de um determinado poder ao produzir verdades. Verdades que desempenham papéis, que têm funções e implicações no corpo social. Verdades que, se não esmagam os homens, produzem indivíduos (docilizados e tornados produtivos) ${ }^{10}$. A inteligibilidade dos campos de saber-poder, se faz, portanto, em torno das verdades que os produzem e apóiam, "em torno do estatuto da verdade e do papel econômico-político que ela desempenha" (1979, p.13). Daí porque, diante dos embates em torno da verdade, do regime de sua produção, a análise deva ser feita "em termos de genealogia das relações de força, de desenvolvimentos estratégicos e de táticas. [...] A historicidade que nos domina e nos determina é belicosa, e não lingüística. Relação de poder, não relação de sentido." (1979, p.5).

A verdade que recebeu guarida no Estatuto da Cidade, a verdade que a partir dele pôde operar de maneira mais desenvolta, encontra-se alicerçada no princípio da função social da propriedade, consagrado na Constituição Federal de $1988^{11}$. No Estatuto, em seu artigo 39, encontra-se a regulamentação do princípio da função social da propriedade urbana. Mas é na consagração de diversos instrumentos urbanísticos (especialmente as operações consorciadas, a outorga onerosa e a transferência do direito de construir), pelo Estatuto da Cidade, que se pode melhor vislumbrar os fundamentos da verdade da reprodução do espaço na e pela urbanização contemporânea.

Para os propósitos deste texto, interessa destacar o que foi estabelecido em sete artigos (28 a 35), distribuídos nas seções IX a XI (Da outorga onerosa do direito de construir; Das operações urbanas 
consorciadas e Da transferência do direito de construir). Neles dispõe-se sobre a fixação de áreas nas quais o direito de construir acima do coeficiente de aproveitamento básico poderá ser exercido; as contrapartidas de seus beneficiários; as condições a serem observadas para a outorga onerosa do direito de construir (prevendo, no inciso II do art.30, a possibilidade de isenção de seu pagamento) e a alteração de uso; a aplicação dos recursos auferidos com o instrumento da outorga onerosa; a delimitação das áreas de implementação das operações consorciadas; a emissão de certificados de potencial adicional de construção e sua negociação para utilização no pagamento das obras necessárias à própria operação; e, finalmente, na Seção XI, dispõe-se sobre a transferência do direito de construir.

Tomados isoladamente, tais instrumentos têm por objetivo (declarado) garantir a equidade dos investimentos públicos no espaço urbano; garantir contrapartidas de proprietários fundiários que se beneficiam dos investimentos públicos em infra-estrutura urbana e, ainda, impedir que retenham suas propriedades por meio da chamada especulação imobiliária. Examinando, porém, mais detidamente em seu conjunto, logo evidenciam-se incongruências. Por exemplo: na seção acerca das operações urbanas consorciadas, existem incisos que objetivam controlar as possibilidades de ganhos privados delas advindas. Assim, estabeleceu-se a obrigatoriedade de contrapartida dos proprietários beneficiários (inciso VI). No entanto, o $\S 1^{\circ}$ do inciso VII do artigo 33 define que "os recursos obtidos pelo poder público municipal na forma do inciso VI deste artigo serão aplicados exclusivamente na própria operação urbana consorciada". Ou seja, ao contrário do que se explicita nas diretrizes gerais (que a lei "estabelece normas de ordem pública e interesse social que regulam o uso da propriedade urbana em prol do bem coletivo" e a política urbana deve respeitar a "justa distribuição dos benefícios e ônus decorrentes do processo de urbanização", entre outras boas intenções ${ }^{12}$ ), os proprietários e investidores das áreas passíveis das chamadas operações urbanas serão, de fato, seus reais beneficiários.

Mas, certamente, é o artigo 34 da seção que trata das operações urbanas consorciadas um dos mais importantes para a movimentação dos capitais que atuam na revalorização do espaço. É neste artigo que se define a possibilidade de emissão pelo poder público de certificados potenciais adicionais de construção que, por sua vez, podem ser negociados livremente e assim adquiridos por investidores privados. Apesar de seu parágrafo primeiro determinar que os referidos créditos edificáveis sejam conversíveis em direito de construir somente na área objeto de operação (o que já é de grande interesse para os capitais atuantes no chamado setor imobiliário), o artigo 35 prevê possibilidade para "o proprietário de imóvel urbano, privado ou público, exercer em outro local, alienar, mediante escritura pública, o direito de construir previsto no plano diretor, ou em legislação urbanística dele decorrente [...]”.

Ora, o fundamental a considerar não são as incongruências constantes no texto legal, mas o fato de que as intencionalidades nele contempladas concernem à institucionalização das racionalidades parciais, e conseqüentes estratégias, próprias ao movimento dos capitais que atuam na urbanização definida como campo de valorização.

Especialmente nas metrópoles, não são raros os espaços que se encontram na situação definida por David Harvey como de inércia geográfica. São espaços considerados deteriorados, nos quais a infraestrutura correspondente a momentos da reprodução capitalista distintos do atual (quando, por exemplo, a industrialização propriamente dita reestruturou as cidades então existentes) encontra-se saturada (obsoleta até), dificultando, por exemplo, o fluxo de tudo e de todos em virtude de uma estrutura viária que se revelou subdimensionada a partir do momento em que a difusão do automóvel se aprofundou. A definição de usos do espaço, delimitando e articulando funções conforme o planejamento urbano, cristaliza níveis de adensamento, coeficientes de edificação e de aproveitamento dos terrenos... As pro- 
priedades imobiliárias, por sua vez, podem ser objeto de litígios, por comportar problemas de titulação, de heranças não resolvidas, inviabilizando assim sua mobilização, bem como podem se encontrar excessivamente desmembradas, ou ainda não parceladas... Enfim, para o reordenamento do espaço, para a sua modernização, o Estado é sempre requerido, na medida em que nele se reúnem meios e condições para a concertação e viabilização dos interesses envolvidos na (re)valorização do espaço, especialmente e sobretudo na redefinição dos patamares de capitalização das rendas fundiárias.

Historicamente, o reordenamento dos espaços urbanos, codificado e recodificado de diferentes formas, sempre implicou na mobilização da propriedade imobiliária. Da remoção de cortiços no Rio de Janeiro na segunda metade do século XIX, conforme apregoado pelo saber médico-higienista e apoiada materialmente pelos empresários da construção civil da época ${ }^{13}$, passando pela reforma Pereira Passos, no início do século passado ${ }^{14}$, até as chamadas revitalizações, requalificações... atuais, com as articulações, inclusive internacionais, com instituições multilaterais de investimento (como Banco Mundial e BID) e os circuitos globais de consultorias urbanísticas, por exemplo, a escala e a complexidade do processo aumentaram enormemente, em virtude dos limites e possibilidades de mobilização da propriedade territorial nos marcos da valorização do espaço.

As chamadas operações urbanas exprimem institucionalmente os atuais requerimentos dessa mobilização. As alterações de uso do solo, a regularização fundiária, a redefinição do parcelamento, dos coeficientes de aproveitamento dos terrenos, a comercialização de quotas para edificação... são instrumentos que indubitavelmente ampliam as possibilidades de mobilização das propriedades. Não se pode descurar, porém, de um ponto por demais precioso: as operações urbanas configuram territórios de valorização do espaço. Nessas áreas, definidas em lei, para as quais são assegurados recursos, busca-se não apenas redefinir os patamares de capitalização das rendas, como salvaguardar as rendas diferenciais produzidas.

Tomemos a ajuda de um exemplo: no contexto dado pelo Estatuto da Cidade dois centros de compras foram construídos em Belo Horizonte. Trata-se do shopping popular Oiapoque e do nada popular Pátio Savassi.

O shopping Oiapoque, que integra as ações do Estado destinadas à reprodução espacial do centro de Belo Horizonte, implementadas através do Programa Centro Vivo ${ }^{15}$, abriga camelôs que foram retirados das ruas do centro e realocados em espaços fechados, os denominados "shoppings populares".

O embate entre Prefeitura (apoiada pelos comerciantes estabelecidos) e camelôs remonta pelo menos ao final da década de 1980, quando estes ocuparam de maneira mais intensa e ostensiva as ruas e calçadas do centro de Belo Horizonte. Naquele momento, foi estabelecida pela Prefeitura como solução dos problemas decorrentes da presença dos agentes desse circuito mercantil o seu confinamento em determinadas áreas, os chamados "camelódromos", especificamente delimitados para a sua atuação e para facilitar a fiscalização pela Prefeitura, porém distantes dos fluxos das pessoas que consumiam as mercadorias por eles vendidas. Nas campanhas eleitorais para prefeito, a retirada dos camelôs do centro era promessa de quase todos os candidatos, uma vez que as tentativas de implementação dos "camelódromos" não se deram sem fortes resistências. Entretanto, o Estatuto da Cidade, o Plano Diretor e o Código de Posturas para a região central compuseram o conjunto institucional que permitiu que os camelôs fossem efetivamente retirados das ruas do centro. Não obstante, seu destino não foram os "camelódromos", uma vez que tal contexto institucional atrelou a solução do que era posto como problema às estratégias de valorização do espaço, de atualização dos patamares de capitalização de propriedades tornadas obsoletas no movimento de reprodução social da metrópole.

A associação da definição da função social da propriedade, da transferência do direito de construir, da outorga onerosa no âmbito das operações urbanas consorciadas foi o lastro institucional de tal estratégia,

Revista da ANPEGE v. 5, 2009 
na medida em que tornou factível a modificação do potencial construtivo de áreas com zoneamentos de adensamento restrito, caso da área onde foi construído o Pátio Savassi, por meio dos créditos edificáveis transferidos de imóveis que passaram a cumprir uma função social (tal como estabelecido no Plano Diretor), por meio de uma operação urbana, caso do imóvel transformado no shopping popular Oiapoque. Embora altamente rentáveis devido à locação dos boxes aos antigos camelôs, os shoppings populares foram considerados equipamentos que cumprem uma função social, o que possibilitou aos proprietários de antigos galpões ou edifícios que compunham a inércia geográfica do espaço central de Belo Horizonte, refuncionalizarem suas propriedades e exercerem a transferência do direito de construir. Ao fim e ao cabo, a transferência do direito de construir evidenciou-se tão ou mais rentável para os proprietários que a locação dos boxes para os camelôs. Isso porque o cálculo dos créditos edificáveis foi definido numa razão de um por três: ou seja, a cada $\mathrm{m}^{2}$ destinado à função social o proprietário recebeu o direito de construção de $3 \mathrm{~m}^{2}$ em outro terreno localizado sob outro zoneamento, conforme definido no plano da Operação Urbana Consorciada do Conjunto Arquitetônico da Avenida Oiapoque. Mesmo que se desconsiderasse o fato desses imóveis encontrarem-se obsoletos antes da constituição dos shoppings populares, só a transferência do direito de construir foi suficiente para reatualizar os patamares de realização da renda territorial.

Através de tais estratégias, propriedades tornadas obsoletas pelo próprio movimento de reprodução social da metrópole, tiveram redefinidos seus patamares de capitalização ao entrarem nos novos circuitos instituídos, nos quais os direitos fundiários não se restringem mais ao solo propriamente dito, podendo ser envolvidos em circuitos onde o que se negocia é a virtualidade da capitalização da renda. Assim a realidade urbana é aberta para novos investimentos de capital, embora crescentemente fechada para a criação de relações sociais não mediadas pelas coisas.

Que o Estatuto da Cidade contou com a participação dos movimentos da sociedade civil que lutam pela reforma urbana, não há dúvidas. Que a criação e recriação de direitos, como é próprio da democracia, foi e continua sendo resultado de árduas e não raro dramáticas lutas que nada têm de quiméricas, ninguém desconhece. Uma genealogia das lutas pelo direito à cidade, porém, demonstraria que embora o desenvolvimento da cidadania para além de suas caricaturas despolitizantes não seja uma bagatela histórica, não se pode confundi-la com a própria democracia. Isso porque a modificação das situações de classe, enquanto fruto da cidadania, não altera os pilares sobre os quais a sociedade encontra-se estruturada e a partir dos quais se reproduz. Sabemos que a expansão da cidadania implica uma ampliação na participação da riqueza socialmente produzida, que impõe modificações nas situações experimentadas pelas classes sociais, o que dificilmente seria acessível a partir das condições que determinam as próprias classes. Inscritos como deveres do Estado, os direitos sociais, enquanto conquistas do exercício dos direitos civis e políticos, impõem-lhe custos, dificultam, senão impedem que frações da riqueza social detida pelo Estado seja diretamente utilizada de acordo com os fundamentos e exigências da acumulação capitalista. Porém, sabemos também que a democracia é mais que um regime jurídico-político cuja culminação residiria na configuração e consolidação do Estado de direito onde estariam asseguradas as prerrogativas da cidadania moderna, exercida através dos direitos (civis, sociais e políticos, tal como consagrados). Em acepção rigorosa, no âmbito do Estado a sociedade civil acaba por realizar a anti-política, uma vez que a objetivação da política enquanto representação, ou a ela limitada, acaba por se converter justamente no seu contrário: ao invés de experiência e momento em que as limitações das racionalidades particulares metamorforsear-se-iam numa racionalidade superior voltada para a totalidade, para o devir criador, conforme as exigências do agir democrático, temos a democracia condenada a vegetar nos limites dos

Revista da ANPEGE. v. 5, 2009 
princípios e das formas prescritas e reconhecidas pelo e a partir do Estado, instrumentalizadas pelas frações da sociedade civil que não almejam senão robustecer suas práticas orientadas pelas respectivas racionalidades privadas, inviabilizando mesmo ações orientadas na perspectiva já reduzida de justiça social. Por isso a instituição democrática da sociedade exige a deslegitimação do Estado (bem como do próprio capital) através da ampliação do campo de atividades sobre o qual podem e devem ser feitas escolhas políticas. Fazer com que a democracia seja ato social, irrigando as demais esferas da vida, exige que a sociedade retome a prerrogativa de autoinstituir-se, retome a autonomia para reencontrar a iniciativa e a criatividade expropriadas para reapropriar-se do controle das condições sociais e históricas de existência e do sentido e finalidade a lhes ser conferido, pois a democracia consiste em assumir seu próprio movimento, encontrar sua existência própria, libertando-se das formas que a aprisionam ${ }^{16}$. Considerada nessa perspectiva, a cidadania constitui uma última fronteira para além da qual os fundamentos da ordem social estariam ameaçados. Em suma, a cidadania, enquanto domesticação da política, não transforma a vida, justamente porque a melhora. ${ }^{17}$

Tal genealogia seria mesmo fundamental para compreender a persistência da verdade da urbanização enquanto espacialidade aprestável para a valorização, das representações (mais ou menos científicas) que se limitam a propor uma urbanização melhorada pela e para a modernização de uma sociedade que se modifica, mas não se transforma. A presença da verdade histórica da urbanização contemporânea que o Estatuto da Cidade fortalece. Na perspectiva da genealogia, aqui advogada, trata-se de uma questão de poder. Para solucioná-la, é necessário considerar que o desenvolvimento de algo existente "é tudo menos o seu progressus em direção a uma meta, menos ainda um progressus lógico e rápido, obtido com um dispêndio mínimo de forças - mas sim a sucessão de processos de subjugamento que nela ocorrem, mais ou menos profundos, mais ou menos interdependentes, juntamente com as resistências que a cada vez encontram, as metamorfoses tentadas com o fim de defesa e reação, e também os resultados de ações contrárias bem-sucedidas." (NIETZSCHE, [1887] 2008, p.66). "Deparando com uma grande força por mais perigosa que seja - a humanidade tem de pensar em como torná-la um instrumento de suas intenções." (NIETZSCHE, [1878, 1886] 2007, 218).

Como diria Michel Foucault, trata-se de "desvincular o poder da verdade das formas de hegemonia (sociais, econômicas, culturais) no interior das quais ela funciona no momento. Em suma, a questão não é o erro [...] é a própria verdade.” (1979, p.14).

\section{NOTAS}

(1) BRASIL. Lei ${ }^{\circ} 10.257$, de 10 de julho de 2001. Disponível em: <http://www.planalto.gov.br/ccivil_03/Leis/ LEIS_2001/L10257.htm>. Acesso em: 10 abr. 2009, 00:00h.

(2) No curso do longo e vasto processo de irrupção do capital a partir das entranhas da feudalidade, Marx ([1867] 1989) descreveu limpidamente como o que denominou de acumulação primitiva assentou não só na monetarização das relações sociais onde a mediação do dinheiro ocupava lugar periférico, como sublinhou que a dissolução, não raro brutal, daquelas relações correspondeu à radicalização da separação entre produtores e meios de produção, através de toda sorte de expropriações do campesinato na Inglaterra, Escócia e Irlanda.

(3) "La hipoteca y la usura han sido los médios y formas empleadas por el capital para librar el obstáculo opuesto por la pequeña propiedad a su libre penetración en la agricultura. En cuanto al crédito, tan reclamado por los campesinos, ésta es precisamente la vía aberta al capitalismo, cualquiera que sea la forma que tome la institución de crédito.” (LEFEBVRE, 1983, p.36). 
(4) Cf., a esse respeito, MARTINS, 1994, esp. cap.II (A aliança entre o capital e a propriedade da terra no Brasil: a aliança do atraso).

(5) “A forma e as fontes da renda (revenue) constituem a expressão mais fetichista das relações da produção capitalista. Está aí a existência dessas relações tal como aparece na superfície, uma existência separada dos nexos ocultos da mediação dos elos intermediários. Assim, a terra passa a ser a fonte da renda fundiária, o capital, a fonte do lucro, e o trabalho, a do salário. A forma distorcida em que se exprime a inversão efetiva reproduz-se naturalmente nas idéias dos agentes desse modo de produção. É uma espécie de ficção sem fantasia, uma religião do vulgar." (MARX, 1985, p.1493-4, grifos do autor).

(6) “Os investimentos realizados nas terras nelas se fixam, transformam a terra de simples matéria em capital-terra, incorporam-se ao solo e passam a pertencer ao proprietário dele quando terminado o contrato de arrendamento. Por isso, observa Marx, "o arrendatário evita todas as melhorias e dispêndios de que não pode esperar completo reembolso durante o prazo do arrendamento.” (MARX, [1894] 1991, p.712).

(7) Diversos autores destacaram tal dificuldade. Referindo-se ao caso francês, Henri Lefebvre afirmou: "Recientemente se han operado otras fusiones en Francia. Por ejemplo, entre el capitalismo agrário y el capitalismo industrial y financiero [...]. De todas formas, la propiedad privada de la tierra no cesa de funcionar. Los propietarios de la tierra se reconstituyen perpetuamente, como prolongación o no de la clase feudal, que exigen uma renta absoluta y parte de las rentas diferenciales. Sin embargo, en otros casos, las fusiones operadas han dado por resultado que se confunda la renta absoluta con las rentas diferenciales, las ganâncias y las superganancias capitalistas, en la categoria de una ganância máxima.” (LEFEBVRE, 1983, p.40-41). Mais ponto menos vírgula, David Harvey advertiu que “[...] las confusiones son igualmente evidentes em los países capitalistas adelantados. En Gran Bretaña [...] la propiedad de tierras ya no existe (si alguna vez existió) como um interés de clase unificado y relativamente homogéneo, sino que comprende grupos variados y heterogéneos que van desde las instituciones antiguas (la Iglesia, la Corona, las grandes propiedades de los aristocratas), pasando por las instituciones financieras (bancos, fondos de seguros y de pensiones) hasta uma amplia gama de dueños individuales y corporativos (incluyendo a los trabajadores que son dueños de sus propias casas) y las agencias del gobierno. Esta heterogeneidad es difícil de reconciliar com la idea de que los terratenientes constituyen 'una de las tres grandes clases en la sociedad capitalista'." (HARVEY, David. 1990, p.349). Apesar das dificuldades apontadas, os antagonismos e solidariedades existentes entre proprietários de terras e de capitais (de modo algum insignificantes), não se tornaram pastosas a ponto de serem indiscerníveis. Em extensa e detalhada pesquisa sobre a reprodução da metrópole de Belo Horizonte, examinada através da produção do espaço denominado Belvedere, Gláucia Carvalho Gomes ateve-se com desvelo a tais relações: “o processo de estabelecimento do zoneamento do Belvedere III [...] foi amplamente determinado não só pela pressão dos proprietários fundiários, mas também pela ação da indústria da construção civil, que, naquele momento específico, uniram forças para o alcance do objetivo comum, porém motivados por interesses diferentes que em breve os colocariam em lados opostos, ou seja, quando a renda da terra se erigisse frente os construtores. Os proprietários fundiários objetivavam deter a propriedade e redefinir o zoneamento, o que exacerbaria a renda da terra que poderiam extrair. A indústria da construção civil, por sua vez, objetivava o estabelecimento deste zoneamento, o que lhes possibilitaria extrair rendas fundiárias e lucros acima da média do setor pela venda do espaço que comportava a representação do resgate de um pretenso modo de vida rompido e perdido [...].Embora esta união logo fosse desfeita, é importante destacá-la porque a mesma esclarece que [...] ambos compõem a classe dos proprietários que, unidos, conseguem arregimentar o Estado na composição de seus interesses. Assim, proprietários fundiários e construtores que atuaram no Belvedere III, longe de serem competidores, foram, de fato, concorrentes e parceiros que, afinal, dividiram as rendas fundiárias possibilitadas pela definição do zoneamento que, no limite, foram pagas, diretamente, pelos consumidores do Belvedere e, indiretamente, pelo conjunto da sociedade.” (GOMES, 2006, p.247-248).

(8) Já nos anos de 1970, Henri Lefebvre advertia sobre a importância decisiva do chamado setor imobiliário no processo geral da acumulação capitalista, chegando a questionar o uso anacrônico do termo. "Durante muito tempo, o 'imobiliário', no capitalismo, só teve uma importância menor. O solo pertencia aos destroços de uma classe vencida, os proprietários fundiários, classe, enquanto tal, de origem feudal. Outrora a construção, ramo de produção 
inicialmente subordinado, quase artesanal, tinha menos importância que a produção do aço ou do açúcar (em que pese o adágio: quando a construção prospera, tudo vai bem). Ora, a situação desse 'ramo' mudou completamente, e não apenas nos grandes países industriais. Para explicar esse fato não basta lembrar os fenômenos gerais de urbanização, a extensão das cidades, os progressos técnicos, etc. É preciso mostrar como e porque o capitalismo apossou-se do solo, do espaço. Daí a tendência disso que outrora foi o 'imobiliário', doravante mobilizado (construções, especulações), tornar-se central no capitalismo, por se tratar de indústria nova, menos submetida aos entraves, saturações, dificuldades diversas que freiam as antigas indústrias. Essa tendência, no entanto, é contrariada. O 'imobiliário’ vê-se tolhido, isto é, relegado a uma posição subordinada, pois o afluxo dos capitais para esse ramo — tanto quanto os abusos especulativos — tende a perturbar os mecanismos reguladores, mais ou menos espontâneos ou controlados, do capitalismo. De tal modo que o ‘imobiliário' (produção e especulação) oscila entre uma função subordinada de retomada econômica, uma função diversionista, uma função de regulação, uma função dominante. De acordo com os momentos, os países etc. Ele entra na desigualdade geral dos setores, dos crescimentos, das situações econômicas.” (LEFEBVRE, [1972] 2008, p.117-118, grifos do autor).

(9) “Com relação ao segmento propriamente imobiliário, este concentrou seus lucros muito mais no equacionamento da boa localização do empreendimento e nas características estéticas do edifício do que em ganhos de produtividade." (BOTELHO, 2007, p.52).

(10) Cf. FOUCAULT, [1969] 2008; FOUCAULT, [1975] 1989; além de textos reunidos em FOUCAULT, [1994] 2006 e em FOUCAULT, 1979.

(11) No inciso XXIII do quinto artigo do capítulo sobre os direitos e deveres individuais e coletivos (que garante, em item imediatamente anterior, o direito à propriedade) e no inciso III do artigo 170 (no capítulo sobre os princípios gerais da atividade econômica), a saber: "Art. 170. A ordem econômica, fundada na valorização do trabalho humano e na livre iniciativa, tem por fim assegurar a todos existência digna, conforme os ditames da justiça social, observados os seguintes princípios: I - soberania nacional; II - propriedade privada; III - função social da propriedade; [...]" (BRASIL. Constituição da República Federativa do Brasil de 1988. Disponível em: <http://www.planalto. gov.br/ccivil_03/Constituicao/Constitui\%C3\%A7ao.htm>. Acesso em: 10 abr. 2009, 00:00h.

(12) "Os homens das épocas de corrupção são espirituosos e caluniadores; eles sabem que há outras espécies de assassínio, além do punhal e do golpe de mão - eles sabem, igualmente, que tudo o que é bem dito é acreditado.” (NIETZSCHE, [1882,1887] 2007, p.74).

(13) Cf. CHALHOUB, 1996.

(14) Cf. BENCHIMOL, 1992.

(15) Encontra-se abrigada sob o Programa Centro Vivo uma série de intervenções estatais que, embora apareçam como fragmentadas, podem ser entendidas como parte do processo que visa redefinir as práticas sociais exercidas no centro de Belo Horizonte. Entre estas ações, destacamos a retirada dos camelôs das ruas, reforma de fachadas, de quarteirões e monumentos e praças, como as da Estação e a Praça Sete. Ao nosso ver, porém, o chamado Centro Vivo se articula ao contexto mais amplo da (re)metropolização de Belo Horizonte, levada a cabo através de outras obras infra-estruturais, como a reforma do aeroporto de Confins, duplicação da Avenida Antonio Carlos e construção da chamada Linha Verde. Articuladas, estas obras são indicativas do patamar em que se encontra na atualidade a reprodução do espaço da metrópole.

(16) A este respeito, cf. RANCIÈRE, 1996 e, sobretudo, ABENSOUR, [1997] 1998.

(17) Recentemente a conclusão da argumentação aqui reproduzida foi a de que a cidadania melhora, mas não transforma a vida (cf. MARTINS, Sérgio. Urbanização e violência: reflexões a partir do livro e do filme "Cidade de Deus”. Geographia, Niterói, ano IX, n.18, dez. 2007, p.33-54). A reformulação agora exposta adveio da elaboração nietzscheana, na terceira dissertação de seu Genealogia da moral, acerca do que chamou de medicação sacerdotal e seus benefícios para o melhoramento do homem: “Apenas o sofrimento mesmo, o desprazer do sofredor, é por ele combatido, não a sua causa, não a doença propriamente - esta deve ser nossa objeção mais radical à medicação sacerdotal. [...] Seria preciso ao menos entender-se quanto ao sentido da palavra 'benefício'. Querendo-se

\section{Revista da ANPEGE v. 5, 2009}


com ela exprimir a idéia de que um tal sistema de tratamento melhorou o homem, não discordo: apenas acrescento que, para mim, 'melhorado' significa - o mesmo que 'domesticado', 'enfraquecido', 'desencorajado', 'refinado', 'embrandecido', ‘emasculado' (ou seja, quase o mesmo que lesado...).” (NIETZSCHE, [1887] 2008, p.119, 131, grifos do autor).

\section{REFERÊNCIAS BIBLIOGRÁFICAS}

ABENSOUR, Miguel. A democracia contra o Estado: Marx e o momento maquiaveliano. Belo Horizonte: Ed. UFMG, [1997] 1998.

BENCHIMOL, Jaime Larry. Pereira Passos: um Haussmann tropical. A renovação urbana da cidade do Rio de Janeiro no início do século XX. Rio de Janeiro: Secretaria Municipal de Cultura, Turismo e Esportes, 1992.

BOTELHO, Adriano. O urbano em fragmentos: a produção do espaço e da moradia pelas práticas do setor imobiliário. São Paulo: FAPESP; Annablume, 2007.

CHALHOUB, Sidney. Cidade febril: cortiços e epidemias na Corte imperial. São Paulo: Companhia das Letras, 1996. FOUCAULT, Michel. A arqueologia do saber. 7ed. Rio de Janeiro: Forense Universitária, [1969] 2008.

FOUCAULT, Michel. Vigiar e punir. 7ed. Petrópolis: Vozes, [1975] 1989.

FOUCAULT, Michel. Microfísica do poder. Rio de Janeiro: Graal, 1979.

FOUCAULT, Michel. Estratégia, poder-saber. 2ed. Rio de Janeiro: Forense Universitária, [1994] 2006 (Coleção Ditos \& Escritos, v.IV).

GOMES, Gláucia Carvalho. A realização da economia política do/no espaço e as (im)possibilidades do Urbano na metrópole contemporânea. Belo Horizonte: Instituto de Geociências da Universidade Federal de Minas Gerais, 2006. (Dissertação de mestrado em Geografia). 380f.

HARVEY, David. Los límites del capitalismo y la teoria marxista. México: Fondo de Cultura Econômica, [1982] 1990.

LEFEBVRE, Henri. La teoría marxista-leninista de la renta de la tierra. In: LEFEBVRE, Henri et al. La renta de la tierra: cinco ensayos. México: Editorial Tlaivalli, 1983.

De l'État: l'État dans le monde moderne. Vol. 1. Paris: Union Générale d'Éditions, 1976.

LEFEBVRE, Henri. Espaço e política. Belo Horizonte: Ed. UFMG, [1972] 2008.

MARTINS, José de Souza. O poder do atraso: ensaios de sociologia da História lenta. São Paulo: Hucitec, 1994.

MARTINS, Sérgio. Urbanização e violência: reflexões a partir do livro e do filme "Cidade de Deus". Geographia, Niterói, ano IX, n.18, dez. 2007, p.33-54.

MARX, Karl. O capital: crítica da economia política. Livro 1. v.2. Trad. Reginaldo Sant'Anna. 12 ed. Rio de Janeiro: Bertrand Brasil, [1867] 1989.

MARX, Karl. O capital: crítica da economia política. Livro III. v.6. Trad. Reginaldo Sant'Anna. 5 ed. Rio de Janeiro: Bertrand Brasil, [1894] 1991.

MARX, Karl. O capital: teorias da mais-valia. História crítica do pensamento econômico.Livro IV. v.3. Trad. Reginaldo Sant'Anna. 5 ed. Rio de Janeiro: Bertrand Brasil, 1985.

MARX, Karl. Elementos fundamentales para la crítica de la economía política (Grundrisse) 1857-1858. v.1, 16 ed. México: Siglo Veintiuno Editores, 1989. 
NIETZSCHE, Friedrich. Humano, demasiado humano: um livro para espíritos livres. Trad. Paulo César de Souza. $2^{\mathrm{a}}$ reimp. São Paulo: Companhia das Letras, [1878, 1886] 2007.

NIETZSCHE, Friedrich. A gaia ciência. Trad. Paulo César de Souza. 4ª reimp. São Paulo: Companhia das Letras, $[1882,1887] 2007$.

NIETZSCHE, Friedrich. Genealogia da moral: uma polêmica. Trad. Paulo César de Souza. 11ª reimp. São Paulo: Companhia das Letras, [1887] 2008.

RANCIÉRE, Jacques. O dissenso. In: NOVAES, Adauto (Org.). A crise da razão. São Paulo: Companhia das Letras, 1996.

RIBEIRO, Luiz César Queiroz. CARDOSO, Adauto Lúcio. Reforma urbana e gestão democrática: promessas e desafios do Estatuto da Cidade. Rio de Janeiro: REVAN: FASE; 2003.

RODRIGUES, Arlete Moyses. Direito à cidade e o Estatuto da Cidade. Cidades. Presidente Prudente, vol. 2, n.3, 2004.

Recebido em abril de 2009

Aceito em agosto de 2009 